\title{
A experiência de integração européia e a evolução do Mercosul
}

\author{
Paulo Roberto de Almeida ${ }^{1}$
}

\section{Experiência européia: um panorama geral sobre avanços e desafios}

Uma avaliação ponderada sobre a experiência européia em termos de integração e seus possíveis ensinamentos para o Mercosul deve partir, fundamentalmente, de uma desmistificação daquela mesma experiência, de maneira a que não apenas não se ofereça ao Mercosul um modelo, suposto ideal, de integração como também para que não se trace de seu itinerário, certamente sinuoso, uma comparação indevidamente mais desfavorável, quando confrontado ao processo, sem dúvida alguma relativamente exitoso, da integração européia.

Aqueles que apontam para os problemas institucionais do Mercosul ou para seu suposto "déficit democrático" como elementos de bloqueio na atual agenda da integração subregional parecem se esquecer, por exemplo, de que a Comunidade Européia ficou durante largo tempo, no início dos anos 60, paralisada pela política de "chaise vide" mantida pela França em face dos problemas de definição de uma política agrícola comum ou de uma definição harmônica dos poderes respectivos

1Doutor em Ciências Sociais pela Universidade de Bruxelas, mestre em Planejamento Econômico, diplomata. Editor Adjunto da Revista Brasileira de Política Internacional (http:// members.tripod.com/rbpi). Autor dos seguintes livros: Relações Internacionais e Política Externa do Brasil; O Brasil e o multilateralismo econômico; $O$ estudo das relações internacionais do Brasil; Mercosul: fundamentos e perspectivas. Co-organizador, com Yves Chaloult, do livro Mercosul, Nafta, Alca: a dimensão social. E-mail: pralmeida@brasilemb.org. As opiniões e argumentos contidos neste trabalho são exclusivamente os de seu autor e não representam posições ou políticas do Ministério das Relações Exteriores ou do Governo brasileiro. 
da Comissão e do Conselho (questão parcialmente resolvida com a institucionalização semi-oficial do Coreper, o Comitê de Representantes Permanentes, ou seja, os Embaixadores dos países membros acreditados junto à Comissão). Da mesma forma, poucos se lembram, hoje, que até quase o início dos anos 80, o Parlamento Europeu era escolhido de forma indireta pelos parlamentos nacionais e que ele tinha de fato muito pouco ou quase nenhum poder consultivo ou realmente deliberativo (ele sequer detém, ainda atualmente, o poder legislativo, monopólio do Conselho ou da Comissão).

Os que se assustam com a descoordenação cambial do Mercosul tampouco se dão conta das assimetrias cambiais e de políticas monetárias que caracterizaram a Europa comunitária na saída do sistema de Bretton Woods, problemas parcialmente resolvidos com a instituição progressiva do Sistema Monetário Europeu (SME), no decorrer dos anos 1970 e 1980. Mas este sistema funcionou, de fato, para um número limitado de países articulados em torno de uma moeda dominante dotada de muita credibilidade (o deutsche mark, ao qual foram estreitamente correlacionados o florim holandês e, numa etapa mais avançada, o franco francês). Os desalinhamentos da lira italiana, da libra britânica e mesmo do franco francês (este durante uma primeira fase de desalinhamento "político") dão testemunho das dificuldades de se lograr um regime cambial coordenado num regime de flutuação de taxas e de movimentação mais ou menos livre dos capitais. Num período bem mais recente, sabe-se que o financiamento "generoso" da unificação alemã, por exemplo, feito à custa de uma elevação sensível das taxas de juros da RFA em 1992, aliado a problemas de instabilidade dos mercados cambiais, provocou o éclatement, ou seja, uma ruptura benigna do próprio SME, que passou a funcionar com margens de flutuação recíproca de +15 e de $-15 \%$, ou seja, de fato a livre flutuação das moedas ainda teoricamente integrantes de uma mesma zona monetária.

Em outros termos, não há via real para o aprofundamento do processo de integração e os países europeus apenas lograram fazer avançar sua construção integracionista porque puderam contar com dois mecanismos relevantes de impulsão comunitária, um de ordem operacional, outro de natureza institucional. O primeiro foi a experiência de mais de 30 anos de coordenação das políticas macroeconômicas e setoriais, forjada na elaboração do orçamento comunitário (politique agricole oblige) e auxiliada pela instituição de um instrumento contábil comum, a unidade de conta chamada de ecu, o que permitiu avançar sem maiores dificuldades de ordem operacional na consecução dos objetivos de Maastricht para a União Econômica e Monetária. O segundo foi o enforcement obrigatório das decisões e das políticas comunitárias, em parte pela Comissão, mas sobretudo pelo Tribunal de 
Luxemburgo, a Corte Européia de Justiça, que pode ser considerado como o verdadeiro "cão de guarda" dos objetivos e dos compromissos do Tratado de Roma de 1957 e, de forma sucessiva, do Ato Único de 1986 e do Tratado da União Européia de 1992.

É evidente que o Mercosul não dispõe nem de uma, nem de outra dessas duas "armas integracionistas", mas também parece claro que, se o seu objetivo não é a construção de um majestoso edifício gótico comunitário erguido no mármore, mas tão somente a de um modesto mercado comum de tijolos e alvenaria, ele não precisa perseguir o ideal de perfeição comunitária que guiou a Europa nos últimos 40 anos, aliás, mais por necessidades externas e internas do que por exclusiva impulsão institucional. Com efeito, não se pode tampouco esquecer que o duplo desafio americano e soviético e a necessidade de superar a "guerra permanente" entre a França e a Alemanha (que desestruturou a Europa e retirou-lhe os comandos da política mundial entre 1870 e 1945) serviram como aguilhões do processo integracionista europeu. Ora, no Mercosul não existe nenhum tipo de competição geopolítica, nenhuma ameaça externa ou interna à inserção internacional (de fato pacífica e sem pretensões hegemônicas) dos países membros e, de fato, pouca densidade relativa nos intercâmbios recíprocos que justifiquem seja, por um lado, o engajamento num empreendimento de custos econômicos razoáveis (pense-se, por exemplo, nas dimensões do orçamento comunitário europeu e nos fluxos de recursos transferidos entre os países), seja, por outro, os custos políticos implícitos numa cessão de soberania pouco compatível, hoje em dia, com as necessidades dos respectivos processos de estabilização econômica.

Em resumo, o Mercosul não tem ainda necessidade estrita, para consolidar os modestos objetivos que são os seus (de bem-estar das comunidades nacionais via unificação dos mercados), de instituir potentes e abrangentes mecanismos de impulsionamento comunitário, mas tão somente do estabelecimento de um marco regulatório mínimo para a conformação desse espaço econômico integrado. Se quisermos retirar ensinamentos da experiência européia, eles poderiam ser resumidos na desejabilidade (e, a partir de um certo momento, na necessidade) de coordenação de políticas monetária, fiscal e cambial e, num outro patamar institucional, na oportuna passagem do sistema arbitral ad hoc para um de tipo permanente e extensivo, prévio à eventual introdução de uma corte de justiça que pudesse dar segurança à ampliação dos negócios internos e à atração de investimentos externos. Para concluir essa parte do "mimetismo europeu", que não se fale de moeda única, pois isso seria simplesmente inexeqüível no presente momento: a moeda comum virá, talvez, no seguimento da conformação de um mercado comum consolidado, se tal é o objetivo de fato dos países membros. 


\section{O Manifesto de Maastricht: gostosuras e travessuras do modelo europeu}

Parodiando o velho Manifesto de 1848, poder-se-ia dizer que um espectro ronda o Mercosul: o espectro da Europa de Maastricht e seus miríficos critérios de unificação monetária. Todos os poderes do mundo acadêmico e os do universo sindical do Cone Sul que se batem pelo avanço concreto do Mercosul, segundo as linhas integracionistas do modelo europeu, parecem ter se lançado numa santa aliança para impulsionar o cenário idealista implícito a esse modelo. O que pedem essas forças do progresso e da democracia? Mais instituições, se possível supranacionais, consagradoras de um regime comum verdadeiramente engajado na realização dos princípios de coesão econômica e social tal como afirmados no Ato Único Europeu; mais direitos sociais ao estilo da Carta Social Européia, supostamente capazes de introduzir o quantum de bem-estar e de justiça social, hoje inviabilizado pelos "capitalistas selvagens" do Cone Sul latino-americano.

Qual mercocrata de plantão não foi descrito como "insensível” por esses idealistas do projeto integracionista? Onde os economistas responsáveis não deixaram de alertar para essa simplificação da realidade da integração no Mercosul em face da complexidade das tarefas ainda remanescentes para cumprir o simples enunciado do Artigo $1^{\circ}$ do Tratado de Assunção? Duas conseqüências derivam desse fato:

- $\quad$ As questões da supranacionalidade e da unificação monetária já fazem parte, por bem ou por mal, da agenda implícita ou explícita do Mercosul;

- Já é tempo que os responsáveis políticos e econômicos do Mercosul eliminem algumas das confusões mentais remanescentes nas cabeças dos partidários de um "Mercosul europeu" e expliquem em face de todo o mundo que o cenário realista traçado pelos "mercocratas" permitiria exorcizar de maneira mais eficaz os perigos que rondam a aplicação de um critério uniformemente integrador a uma realidade pré-união aduaneira que é, de fato, a situação atual do Mercosul.

De fato, o processo de integração no Mercosul tem sido habitualmente avaliado - e julgado, o que me parece ainda pior - à luz do precedente histórico europeu e segundo critérios analíticos derivados da experiência institucional européia. Sem pretender refazer a história ou reinventar a roda - como se diz em relação a progressos tecnológicos dirigidos a resolver problemas práticos -, quer-me parecer que as possibilidades organizacionais de instituir-se um mercado comum com forte embasamento nas realidades econômicas locais dos países do Mercosul não se esgotam no modelo europeu consagrado a partir de 1951 (Ceca) e de 1957 (MCE). Uma tal atitude de adesismo institucional pode na verdade demonstrar uma certa 
preguiça conceitual dos analistas acadêmicos ou ainda uma derivação da velha constatação keynesiana de que somos, de uma forma ou de outra, prisioneiros de algum economista morto, neste caso, condenados a repetir a genial arquitetura concebida e implementada pelos founding fathers da integração européia.

Nunca é demais insistir sobre as particularidades desse processo de integração, seu alto sentido geopolítico - no contexto dos terríveis conflitos que ensangüentaram a Europa durante a segunda "guerra de trinta anos" entre 1914 e 1945-, seu aspecto funcional no quadro da Guerra Fria e da sustentação americana à união e integração européia, assim como as especificidades econômicas e políticas que presidiram à construção progressiva do belo edifício "gótico" - pela sua complexidade, mais do que pela sua arquitetura - que hoje constitui a União Européia. Em alguns momentos desse processo, pode-se até dizer que os meios passaram a justificar os fins, tal o crescimento da "razão burocrática" no âmbito da Comissão e órgãos associados e as aventuras e tribulações da "loucura agrícola comum", para ficar apenas nos dois exemplos mais conhecidos do gigantismo europeu.

Frente a esse quadro de overload institucional deveria o Mercosul tomar a atual EU como modelo e pretender que, segundo a frase latina bem conhecida, de te fabula narratur? Pessoalmente acredito que assim como, no passado, os juristas e estadistas latino-americanos já deram mais de uma prova de sua inventividade conceitual e institucional- como evidenciado, entre outros exemplos, pelas doutrinas Calvo e Drago, pelos diversos instrumentos e instituições políticas pan-americanas -, poder-se-ia igualmente conceber alguma construção relativamente inédita nos anais das experiências integracionistas conhecidas.

Aliás, o Mercosul é certamente híbrido do ponto de vista institucional e não há porque pensar que o modelo comunitário europeu constitui o nec plus ultra dos padrões aceitáveis de construção de um mercado comum. A lógica do Mercosul, à diferença provavelmente da experiência européia, é a do menor custo possível, político ou social, para não dizer econômico, daí a própria economia feita pelos países membros em número de "mercocratas" e outros gêneros de tecnocratas. A própria rationale para a existência de uma entidade integracionista no Cone Sul latino-americano é, deve-se reconhecer, de menor apelo político e de menor justificativa econômica, comparativamente, por exemplo, à justificativa de segurança nacional e de détente militar embutida no Memorandum Monet sobre a integração - de fato fusão- dos complexos carvão e aço de França e Alemanha.

No que se refere à possibilidade de formação de uma ordem jurídica comunitária no Mercosul, não se deve tomar como óbvio o conceito oriundo do direito comu- 
nitário europeu, isto é, de uma ordem autônoma e hierarquizada, implicando uma cessão de soberania por parte dos Estados-Membros. Visto de uma perspectiva propriamente latino-americana, o edifício europeu comporta virtudes e deformações, não porque seu modelo institucional seja politicamente inexeqüível, de maneira absoluta, ao sul do Equador, mas porque ele pode ser, tão simplesmente, na atual conjuntura econômica e geopolítica do cenário mercosuliano, historicamente desnecessário. Assim como não se pode exportar democracias - pois elas dependem mais de uma cultura política e de um ethos social e mesmo societal, do que de simples instituições políticas-, tampouco se poderia conceber uma exportação de modelos integracionistas. Os juristas podem até recusar esse tipo de argumento, passando a responder que uma ordem legal garantidora de normas e de procedimentos ritualizados é absolutamente indispensável ao bom funcionamento de todo e qualquer empreendimento integracionista. Talvez eles até tenham razão, mas então o Mercosul se faz pelo método do ensaio e erro, da empiria consagrada em norma, o que pode não ser uma má idéia em vista de sua ainda baixa densidade intrínseca em termos de conteúdo econômico integracionista.

\section{A agenda do Mercosul: back to the future ou a Europa dos golden sixties}

Qual seria, portanto, uma agenda realista para o Mercosul na presente fase do processo de integração? Comecemos agora por examinar a "hipótese" em função da qual foi elaborado o próprio projeto do Mercosul, ou seja, a realização do mercado comum sub-regional. A terem sido cumpridos os objetivos fixados no Artigo $1^{\circ}$ do Tratado de Assunção, o mercado comum previsto deveria ter entrado em funcionamento no dia $1^{\circ}$ de janeiro de 1995 , o que obviamente não foi o caso. Segundo uma leitura otimista desse instrumento diplomático e do próprio processo de integração, esses objetivos serão cumpridos nesta etapa complementar, que poderíamos denominar de "segunda transição", observados os prazos fixados no regime de convergência estabelecido para os diferentes setores definidos como "sensíveis" e cumpridos os requisitos mínimos desse mercado comum. Isto significaria, entre outros efeitos, a implementação efetiva da Tarifa Externa Comum e a conformação eventual, se necessário, de exceções verdadeiramente "comuns" a essa pauta aduaneira, e não listas nacionais de exceções como hoje se contempla. Idealmente, todas as barreiras não-tarifárias e medidas de efeito equivalente deveriam ter sido suprimidas. A coordenação de políticas macroeconômicas, nessa perspectiva, supõe igualmente que os países membros deveriam ter delimitado 
todas as áreas cruciais de cooperação em vista da necessária abertura recíproca de seus mercados a todos os bens e serviços dos países membros, inclusive no que se refere à oferta transfronteiriça de serviços e ao mútuo reconhecimento de normas e regulamentos técnicos específicos.

$\mathrm{Na}$ ausência de progressos mais evidentes nessas áreas, se esperava que os países pudessem ter definido, pelo menos, um sistema de paridades cambiais com faixas mínimas de variação, se alguma, entre as moedas respectivas, bem como a harmonização dos aspectos mais relevantes de suas legislações nacionais relativas a acesso a mercados. Estes são os requisitos mínimos para a conformação de um amplo espaço econômico conjunto no território comum aos países do Mercosul, a partir do qual se poderia caminhar para a consolidação progressiva e o aprofundamento do processo de integração, em direção de fases mais avançadas do relacionamento recíproco nos campos econômico, político e social.

Ainda que esse cenário razoável não se concretize, como parece previsível, nos primeiros anos do próximo século, seu desdobramento faz parte da lógica interna do Mercosul. Em todo caso, ele resultaria num Mercosul muito próximo do padrão de integração apresentado pelo mercado comum europeu em finais dos anos 60 . Operando um "retorno ao passado" da integração européia, o Mercosul se encontraria na situação do velho Mercado Comum Europeu, dos golden sixties e começo dos seventies, isto é, após terem os signatários originais do Tratado de Roma completado sua união aduaneira e definido uma espécie de "coexistência pacífica" entre uma pretendida vocação comunitária encarnada na Comissão, mas freada pelos representantes dos países-membros nos conselhos ministeriais - e um monitoramento de tipo intergovernamental, consubstanciado no papel político atribuído ao Coreper, o Comitê de Representantes Permanentes, não previsto no primeiro esquema institucional. Em outros termos, mesmo a mais "comunitária" das experiências integracionistas, sempre foi temperada por um necessário controle intergovernamental ou, melhor dizendo, nacional.

No caso específico do Mercosul, as dúvidas ou obstáculos levantados em relação ao aprofundamento do processo de integração não parecem derivar de reações epidermicamente "soberanistas" ou mesquinhamente nacionalistas - ou até mesmo "chovinistas", como parecem acreditar alguns- mas de determinadas forças políticas ou de correntes de pensamento, para não falar de interesses setoriais "ameaçados", que logram "congelar" o inevitável avanço para a liberalização comercial ampliada entre os membros. Tais tendências não são necessariamente nacionalmente definidas, mas existem ao interior de cada um dos países envolvidos no processo. 
Não se poderia, por exemplo, excluir a hipótese de também o Mercosul vir a instituir, em Montevidéu, uma espécie de Coreper, mas parece evidente que esse eventual "órgão" informal teria mais a função de assessorar o trâmite de matérias administrativas junto à Secretaria Administrativa ou de facilitar o contato "diário" entre os quatro países do que, como no exemplo original europeu, os objetivos de "controlar" um órgão legitimamente comunitário - a Comissão -, estabelecer-lhe limites no processamento das atividades de "rotina" (definidas em função dos "interesses nacionais") e, também, de acelerar o trâmite de matérias julgadas relevantes pelas capitais. Sua institucionalização requereria uma mera "emenda", por via de decisão ministerial, ao Protocolo de Ouro Preto, mas também parece evidente que seu significado político transcenderia o simples aspecto de um "acabamento" na incipiente estrutura organizacional da união aduaneira.

Quais seriam, em conseqüência, as opções razoáveis, ou as mais prováveis, que se apresentam para compor uma agenda em torno do desenvolvimento futuro do Mercosul? Elas se situam, claramente, no campo de seu aprofundamento interno, em primeiro lugar nos terrenos econômico e comercial, no âmbito de sua extensão regional, no reforço das ligações extra-regionais (em primeiro lugar com a União Européia) e, finalmente, mas não menos importante, no apoio que o Mercosul pode e deve buscar no multilateralismo comercial como condição de seu sucesso regional e internacional enquanto exercício de diplomacia geoeconômica.

Parece evidente que, a despeito de dificuldades pontuais e de obstáculos setoriais, a marcha da integração econômica não poderá ser detida pelas lideranças políticas que, nos próximos cinco ou dez anos, se sucederão ou se alternarão nos quatro países membros e nos demais associados. Tendo resultado de uma decisão essencialmente política, de "diplomacia presidencial" como já se afirmou, o Mercosul econômico não poderá ser freado senão por uma decisão igualmente política. Ora, afigura-se patente que o processo de integração possui um valor simbólico ao qual nenhuma força política nacional tem a pretensão de opor-se. Daí se conclui que os impasses comerciais, mesmo os mais difíceis, tenderão a ser equacionados ou contornados politicamente e levados a uma "solução" de mútua e recíproca conveniência num espaço de tempo algo mais delongado do que poderiam supor os adeptos de rígidos cronogramas econômicos. Nesse sentido, o Mercosul não é obra de doutrinários ortodoxos, mas de líderes pragmáticos.

Assim, sem entrar na questão do cumprimento estrito do programa de convergência ou no problema da compatibilização de medidas setoriais nacionais, tudo leva a crer que a futura arquitetura do Mercosul econômico não seguirá processos 
rigorosamente definidos de "aprofundamento" inter e intra-setoriais, dotados de uma racionalidade econômica supostamente superior, mas tenderá a seguir esquemas "adaptativos" e instrumentos ad hoc essencialmente criativos, seguindo linhas de menor resistência já identificadas pragmaticamente. Se o edifício parecer singularmente "heteróclito" aos olhos dos cultores dos esquemas integracionistas pode-se argumentar, em linha de princípio, que o itinerário do Mercosul econômico não precisa seguir, aprioristicamente, nenhum padrão de "beleza estética" ou de "pureza teórica" no campo da integração. Em qualquer hipótese, o Mercosul não está sendo construído para conformar-se a padrões organizacionais previamente definidos em manuais universitários de direito comunitário, mas para atender a requisitos econômicos e políticos de natureza objetiva, que escapam - e assim deve ser - a qualquer definição teórica ou pretensa coerência metodológica.

No que se refere à questão do aprofundamento interno, político e institucional do Mercosul, eventualmente inclusive no terreno militar, não se pode deixar de sublinhar, uma vez mais, as dificuldades inerentes - e as demandas inevitáveis, pelos protagonistas já identificados - vinculadas ao problema da supranacionalidade, constantemente agitado, como uma espécie de "espantalho acadêmico", sobre a mesa de trabalho de "mercocratas insensíveis". Não se poderia excluir, a esse respeito, a evolução progressiva do atual principal opositor a qualquer "renúncia de soberania" no âmbito do Mercosul, o Brasil, em direção de uma posição mais próxima, intelectualmente falando, dos demais países-membrosseja os declaradamente "supranacionais", como Uruguai e Paraguai, seja a Argentina moderada, isto é, em favor de uma combinação de instituições intergovernamentais e comunitárias -, muito embora tal questão esteja em conexão direta com a definição de um outro tipo, ponderado, de sistema decisório interno à união aduaneira.

\section{Evolução recente (política, econômica e institucional) do Mercosul}

A despeito das dificuldades atuais e do recuo conjuntural dos fluxos de intercâmbio, deve-se reconhecer que o Mercosul é um dos mais bem sucedidos empreendimentos integracionistas não só na América Latina mas em todo o mundo em desenvolvimento, tanto em termos de crescimento do comércio e dos nexos de interdependência recíproca, como em virtude de uma inédita estrutura institucional adaptada aos requerimentos da união aduaneira em construção, caracterizada por uma arquitetura híbrida, flexível, econômica e sobretudo altamente interativa com os centros de decisão dos respectivos poderes executivos dos países membros. 
O crescimento do comércio intrarregional, exponencial em relação à expansão do comércio individual dos países membros, não se fez em detrimento de terceiros, mas sim desenvolveu-se no contexto de processos de abertura econômica e de liberalização comercial, consoante o modelo de regionalismo aberto que marcou o seu desenvolvimento.

Todos os prazos estabelecidos consensualmente foram razoavelmente cumpridos, tanto no que se refere à formação da Zona de Livre Comércio (eliminação das listas nacionais de exceção, com pequenas derrogações no conjunto), como no que tange à implementação da União Aduaneira (cujos prazos de convergência estão sendo respeitados na quase totalidade dos casos). Situações peculiares da ZLC (açúcar, regime automotivo) devem ser equacionados internamente no futuro próximo. O aumento linear em três pontos da Tarifa Externa Comum cessará de vigorar no final do ano 2000 e a quase totalidade do comércio extra-comercial da UA funcionará segundo o seu regime normal, de 0 a $20 \%$ (automóveis terão um prazo adicional na alíquota de $35 \%$ ).

Todas as reuniões dos órgãos permanentes do Mercosul vêm desenvolvendose normalmente e, se o comércio vem apresentando como se sabe dificuldades no período recente, não se pode de nenhuma forma falar de crise política ou de bloqueios institucionais. A Comissão de Comércio do Mercosul e o Grupo Mercado Comum vêm dando conta de maneira eficaz de suas agendas respectivas e o Conselho do Mercado Comum tem, sob a impulsão dos presidentes, logrado enfrentar a contento os desafios que tem sido colocados aos executivos nacionais no processo de plena implementação da UA. Não se pode, aliás, deixar de reconhecer que a chamada diplomacia presidencial tem servido de fator de diluição dos desentendimentos (normais) entre os países membros numa fase decisiva de "cessão" adicional de soberanias.

A participação da comissão parlamentar e do Fces, este foro representando a sociedade civil, tem igualmente se estendido a uma gama cada vez maior de temas, dando respaldo aos órgãos institucionais de caráter político ou ao trabalho dos grupos técnicos. O debate em torno do chamado "salto supranacional", num momento reivindicado por juristas e acadêmicos, revelou-se uma falsa questão e hoje quase ninguém mais contesta, em bases objetivas, a opção de Ouro Preto pela atual arquitetura institucional do Mercosul.

\section{Problemas e dificuldades do "segundo período de transição"}

Os poucos percalços que enfrenta atualmente o processo de integração, se examinados bem atentamente, não correspondem a problemas do Mercosul, mas 
em grande medida a problemas dos próprios países membros. Se não vejamos: os desequilíbrios de balanças comerciais não são derivados de fluxos desestabilizadores que tenham origem no comércio intra-Mercosul, assim como os déficits de transações correntes não podem ser considerados como tendo sido provocados pelo intercâmbio de serviços e de fatores na própria região. Esses desequilíbrios se explicam pelos fluxos globais de bens e serviços (inclusive rendas do capital) que entretêm os países membros individualmente com parceiros de fora da região e de maneira ampla com o resto do mundo, como parece evidente tanto no caso do Brasil, como no da Argentina. Os fluxos intra-Mercosul têm servido, sobretudo, como elementos anticíclicos em momentos de dificuldades conjunturais para cada um dos países membros.

Nenhuma defasagem cambial pode ser imputada ao Mercosul enquanto tal, mas tal tipo de problema aparece como o resultado de opções políticas e econômicas propriamente nacionais, tomadas largamente num contexto de restrições externas ou de diminuição de opções internas determinadas independentemente e à margem do processo de integração. Da mesma forma, a atual fase de não-coordenação de políticas macroeconômicas não expressa uma suposta escolha anti-integracionista de um ou outro país, mas representa a ausência objetiva de condições para a efetivação dessa coordenação, situação reconhecida de boa-fé por todos os economistas atentos aos desenvolvimentos do Mercosul nesta sua "segunda fase de transição".

O que é essa "segunda fase de transição"? Ela representa o período adicional necessário à consecução dos requisitos indispensáveis à conformação do mercado comum simplificado que se está pretendendo criar na sub-região, ou seja, justamente, a coordenação de políticas macroeconômicas e a harmonização de políticas setoriais prometidas pelo Art. $1^{\circ}$ do Tratado de Assunção (TA). As disputas comerciais internas são bem menos relevantes, nessa ótica, do que a definição de regras estritas a serem aplicadas nos terrenos da política industrial, da concorrência, dos incentivos aos investimentos, de aplicação de normas e regulamentos técnicos, de definições nos terrenos dos financiamentos e da abertura no setor de serviços com preservação de uma certa preferência regional.

Não há, absolutamente, nenhuma crise do que se poderia chamar de "programa doutrinário da integração", mas tão simplesmente dificuldades naturais por acesso recíproco aos mercados dos países membros em áreas bem delimitadas, ou seja, problemas que correspondem a uma situação de abertura progressiva num contexto de indefinição de normas estritas de competição e de ausência parcial ou total da "harmonização das políticas macroeconômicas". 


\section{Os desafios internos e externos ao Mercosul são alavancas ou bloqueios ao seu avanço?}

Outras dificuldades advêm, como é também natural, da percepção diferenciada que têm os países membros quanto a seus interesses nacionais no âmbito dos processos negociatórios dentro e fora da região em que eles estão coletiva ou individualmente engajados. CAN-Alcsa, Alca, Rodada do Milênio da OMC, UEMercosul são exemplos de desafios externos que já se colocaram ou que devem se colocar no difícil processo de harmonização e concertação de posições em vista dessas negociações. Tomando-se como ponto de partida situações de baixa densidade intrínseca de interdependência ou de complementaridade econômica recíproca e diferentes tipos de inserção econômica internacional, é explicável que os países membros do Mercosul apresentem ainda divergências na maneira de encarar a agenda negocial externa.

No plano interno, o desafio mais óbvio é o da sustentação continuada dos respectivos processos de estabilização macroeconômica, que por sua vez se desdobra em novo desafio externo, o da manutenção da credibilidade de suas políticas econômicas, base indispensável para o acesso aos créditos, investimentos e financiamentos internacionais.

Nenhum desses problemas ou desafios, contudo, requer uma parada ou recuo no processo de integração, mas, sim, eles parecem exigir o comprometimento dos países com etapas ainda mais avançadas de construção do edifício integracionista. Os problemas da integração - que como explicitado acima não são propriamente provocados pela integração - pedem mais, e não menos integração. Não se trata de estabelecer agendas voluntarísticas, como se, por exemplo, a atual ausência efetiva de coordenação de políticas macroeconômicas requeresse, de fato, a fixação de um calendário para a introdução de uma moeda comum, pois isso apenas traria ainda menos credibilidade externa ao Mercosul do que parecem gozar hoje os países membros tomados individualmente.

Parece claro, no entanto, que cada vez que o Mercosul foi colocado em face de desafios similares, ele soube responder de forma convincente com graus razoáveis de coordenação política e diplomática entre os países, sobretudo no caso de seus dois parceiros maiores.

\section{O Mercosul deve consolidar-se como simples ZLC ou evoluir para uma união aduaneira?}

A questão da coordenação de políticas apresenta pouca relevância para a situação em que se encontra, de fato, o Mercosul atualmente: isto é, a consolidação de 
sua ZLC, aliás uma base indispensável à formação da projetada Alcsa, pouco proclamada nos discursos, mas na verdade implícita nos desenvolvimentos recentes do processo negocial na América do Sul. Que o Brasil tenha dado a partida a esse processo (precisamente durante a gestão do Embaixador Rubens Antônio Barbosa à frente da área econômica do Itamaraty, tendo o Presidente Fernando Henrique Cardoso como chanceler), nada mais natural, uma vez que se trata do principal mercado consumidor e da maior potência industrial do continente. $\mathrm{O}$ Brasil se encontra, assim, em escala continental, na mesma situação da Inglaterra vitoriana, quando esta decretou ofree-trade universal em meados do século XIX: cabe ao Brasil decretar uma espécie de free-trade continental e fornecer as bases para a conformação de uma vasta zona de comércio liberado no Cone Sul, antes que o hemisfério seja engolfado nos projetos livre-cambistas bem mais ambiciosos (e de fato hegemônicos, mesmo involuntariamente) da grande potência do Norte. Temos hoje condições únicas para liderar o processo subregional, e para isso não se necessita, ou pelo menos não se depende, do estabelecimento de uma união aduaneira no Mercosul, mas tão somente de condições relativamente igualitárias de acesso ao mercado brasileiro como forma de levar todos os parceiros à mesa negociadora.

Na perspectiva das negociações hemisféricas, é certo que quanto mais avançado estiver o Mercosul, melhor será sua força de barganha e sua credibilidade política na mesa negociadora. Mas, realisticamente, o Mercosul precisaria eventualmente evoluir para uma UA apenas e tão somente se a Alca for uma realidade plausível no horizonte de 2003-2005, o que poderá ser melhor aferido se uma presidência e um Congresso uniformemente republicanos nos EUA lograrem obter um mandato preciso o chamado fast-track para conduzir, junto com o Brasil, a última fase do processo negociador. Nesse caso, a UA do Mercosul, que significa igualmente a coordenação estrita da política comercial da união aduaneira em consolidação, serviria não apenas para reforçar o grau de coesão interna dos países membros como também para preservar algumas margens de preferências que podem revelar-se úteis no jogo de barganhas e de ulterior competição aberta que passariam a caracterizar o espaço hemisférico depois de 2005. Ressalte-se, finalmente, que o fato de o mandato de Miami ter dado o prazo de 2005 para a conclusão de negociações em torno de uma Alca, não significa que essa Alca tenha de começar a ser implantada já em 2006. Restaria, assim, um prazo prudencial para que o Mercosul consolidasse sua união aduaneira mesmo numa "terceira fase de transição" pós-2005. 


\section{Quando e por que ele deveria postular-se como mercado comum e não como simples UA?}

Essa pergunta é dependente, obviamente, do projeto estratégico comum, de longo prazo, dos quatro países membros, ou pelo menos do cenário estratégico que o Brasil, como seu maior protagonista, pretenda traçar para sua própria inserção econômica internacional e para sua política externa neste começo de século XXI. Deve-se começar por uma verdade muito simples, mas que algumas vezes é esquecida por aqueles que consideram a experiência européia como uma espécie de nec plus ultra dos processos integracionistas possíveis e imagináveis: não se faz um mercado comum pelo simples prazer estético de se partilhar mercados, pela auto-satisfação de se afirmar uma política comum nos mais diversos setores da atividade produtiva ou pela compulsão de abrir fronteiras ao intercâmbio de pessoas, capitais e coisas. Um mercado comum não é senão um meio, como tantos outros, de se promover políticas de bem estar e programas de desenvolvimento. Sua rationale é a da concorrência e da abertura como forma de estimular a inovação, a eficiência econômica e o estímulo a graus ainda maiores de inserção internacional, que não são bens coletivos em si, mas simples mecanismos para aumentar a eficiência geral do sistema econômico e o grau de bem-estar da comunidade nacional (sublinho o conceito nacional, uma vez que o horizonte da soberania estatal ainda está longe de ter sido superado na consecução dos objetivos ditos permanentes da Nação).

Aceitas estas considerações, o mercado comum do Mercosul apenas deve e poderá existir se e quando os países membros definirem metas comuns nas áreas das políticas setoriais e macroeconômicas como o meio mais adequado para a realização de seus objetivos nacionais e internacionais. Não se deve ter ilusões: o mercado comum só tem condições efetivas de se realizar se ele responder a necessidades objetivas dos processos nacionais de estabilização macroeconômica, de inserção produtiva de cada um de seus sistemas econômicos nacionais (por certo, progressivamente integrados e interdependentes), e, finalmente, de aumento do bem-estar das populações de cada um dos países participantes nesse empreendimento. A invocação do mercado comum como um objetivo desligado e autônomo dessas metas individuais dos países membros não tem a força mobilizadora que lhe atribuem muitos dos românticos acadêmicos da integração sub-regional. Não estamos engajados num processo, por certo difícil de cessão de soberanias e de construção de um edifício razoavelmente complexo em termos de administração pública compartilhada, para atender a qualquer tipo 
de profecia bolivariana, por mais nobres que possam ser tais metas solidaristas. O objetivo estratégico, pelo menos o do Brasil, não esqueçamos essa verdade muito simples, é, antes de mais nada, o de elevar o padrão de vida da comunidade nacional, e apenas em segundo lugar viriam quaisquer outros objetivos de política econômica ou de política externa.

A conformação do mercado comum do Sul, nome e mandato originais do Mercosul, deve portanto obedecer a esse objetivo de simples bom senso e de modesto comprometimento comunitário. Se o mercado comum for o instrumento mais adequando à consecução daqueles objetivos, tanto melhor: ele deve ser julgado à luz de sua adequação e funcionalidade a tais metas, e não o contrário. Parece, contudo, razoável supor que um grau adequado de avanço na construção do mercado comum seja uma espécie de préalable e de garantia à afirmação interna e externa do Mercosul no cenário de blocos estratégicos e de zonas preferenciais que ainda marcarão o horizonte das relações internacionais no limiar do século XXI. Com efeito, parece lícito supor que os progressos da liberalização multilateral e os avanços práticos tanto no terreno do direito internacional como no da interdependência econômica não serão tão importantes no cenário previsível pósRodada do Milênio e de fim definitivo dos últimos experimentos socialistas do planeta como para se renunciar à "arma” do regionalismo enquanto vetor prático, por vezes, necessário, da afirmação dos interesses nacionais num mundo em que, a despeito da interdependência global, sempre alguns serão mais "interdependentes" do que outros. Nesse caso, a interdependência de um mercado comum é mais administrável, no plano das políticas públicas, do que a interdependência saudavelmente anárquica do não-sistema político mundial e de fato multipolar em que vivemos hoje. Aliás, até como uma defesa contra o hegemonismo, o mercado comum pode apresentar certas vantagens intrínsecas.

\section{A arquitetura institucional do Mercosul: modéstia e bom senso}

Caberia, no futuro próximo, promover avanços notáveis no plano político e institucional do Mercosul? Não necessariamente, pois que uma eventual "mercocracia" comodamente instalada em Montevidéu não será necessariamente mais eficiente do que as burocracias nacionais coordenadas entre si; ao contrário, ela pode até ser mais "alienada" das realidades nacionais, regionais ou locais, num contexto bem diferente, recorde-se, em que sempre atuou a "eurocracia" comunitária, virtualmente soterrada por massas de informações relevantes provindas de Estados relativamente mais eficientes do que os do Cone Sul. Alguém poderia, em 
sã consciência, argumentar que alguns burocratas mercosulianos "iluminados" serão mais imaginativos e eficientes do que seus contrapartes nacionais trabalhando de forma coordenada?

Caberia, sim, portanto, impulsionar a coordenação dos aparelhos estatais entre si, nas mais diferentes esferas de atuação das agências públicas nacionais e das tecnoburocracias especializadas, sempre tendo presente o objetivo da eficiência e do menor custo possível. Não se pode estabelecer políticas comuns, como na Europa, pensando na hipotética projeção externa e internacional de um espaço integrado (minimamente) que permanecerá, de fato, no futuro previsível, um importador líquido de capitais, tecnologia e know-how de países e regiões mais avançados do ponto de vista econômico e tecnológico.

Se o Mercosul se consolida enquanto mercado comum, ele poderá, então, pensar numa moeda comum, em políticas comuns em diversas áreas de interesse conjunto (inclusive, por que não, no terreno militar) e sobretudo em afirmar uma nova personalidade internacional que não será apenas a de um captador de inteligência externa, mas também a de um provedor de recursos e de serviços para outros parceiros nos quais possa haver espaço para o engenho e arte de suas empresas e agentes econômicos. Como já disse o Embaixador Rubens Antônio Barbosa em ocasiões anteriores, as instituições do Mercosul devem ser definidas segundo suas funções e não o contrário, ou seja, criar instituições para somente então darlhes atribuições específicas. Volto a afirmar, o Mercosul não é uma finalidade em si; ele é um meio, ainda que o mais importante da política externa do Brasil contemporâneo.

Tendo em conta as observações realistas efetuadas no presente texto e do ponto de vista do direito internacional, não se pode alegar quebra de compromissos no âmbito do Mercosul, uma vez que não foram definidos, seja no Tratado de Assunção, seja nos demais instrumentos "constitucionais" (Protocolos de Ouro Preto, de Brasília) e nas medidas "legais" do Mercosul, consubstanciados em diferentes resoluções e decisões de seus órgãos diretivos, a definição de objetivos estritamente calendarizados - além da liberalização comercial - ou metodologias específicas para a construção do mercado comum. Trata-se mais de um programa e antes um processo do que um conjunto de compromissos estrita e precisamente definidos. Se é verdade que pretendemos uma longa vida ao Mercosul, e seu sucesso continuado enquanto projeto estratégico para a inserção conjunta de seus países membros no sistema econômico e político internacional do século XXI, então devemos colocar o direito a serviço da economia, e não o contrário. Qualquer 
tentativa de ignorar as condições concretas de existência da RealOekonomie do Mercosul, substituindo-as pelas promessas miríficas da idealPolitik de muitos acadêmicos e observadores descompromissados com o processo negocial e desligados da vida econômica real nos países membros, estaria condenada ao fracasso e contribuiria, contraditoriamente, para o descrédito interno e externo do Mercosul.

Em conclusão, aqueles que acusam o Mercosul de "fadiga burocrática", de "descolamento da vida social", de ignorar ou de desprezar a chamada "participação cidadã" no processo negociador, ou de qualquer outro "pecado" real ou imaginário em relação a um suposto modelo ideal de integração - aliás, jamais definido de modo claro - provavelmente não se dão conta da extrema complexidade e mesmo da própria "temeridade" da construção integracionista no Cone Sul latinoamericano, sobretudo numa fase de tensões econômicas de ordem interna e externa e de elevação inevitável dos custos relativos do desmantelamento das barreiras ainda existentes à liberalização total dos fluxos internos de bens e serviços. Esses críticos "críticos" do Mercosul são usualmente os mesmos que pedem, e de fato reclamam, políticas setoriais mais ativas por parte dos estados membros e diversas outras medidas de apoio às indústrias nacionais, sem atentar para o contraditório das posições assumidas nesse tipo de argumentação. O segredo do sucesso do Mercosul, até o presente momento, tem sido o seu caráter pragmático, bem como a postura realista, e mutuamente compreensiva (para não dizer leniente) assumida pelos Governos dos países membros, em face dos notórios problemas e dificuldades do processo de integração. Sua preservação enquanto experiência até aqui bem sucedida de internacional dependerá, precisamente, da manutenção desse caráter flexível. 
